\title{
The Relation Between Disaggregated Restructuring Charges And Stock Returns: The Effects Of Financial Distress
}

Darlene Anderson (email: dma8747@garnet.acns.fsu.edu), Florida State University Carol Callaway Dee (email: cdee@ cob.fsu.edu), Florida State University

\begin{abstract}
We examine the relation between restructuring charge components and stock returns for firms reporting restructuring charges in the year disaggregated component disclosure became mandatory. We find significant coefficients on disaggregated components of restructuring charges in a regression of returns on earnings, earnings changes, and restructuring charge components. We provide evidence that for firms that exhibit signs of financial distress, aggregate restructuring charges, as well as the disaggregated components of restructuring charges, are priced differently than they are for financially healthy firms. Results suggest that for financially distressed firms, investors perceive supplemental disclosure as a positive signal of the firm's future operating performance, and view negatively a disclosure that lacks detail and/or clarity.
\end{abstract}

\section{Introduction}

Among the problem areas specifically addressed in former SEC Chairman Arthur Levitt's 1998 speech, "The Numbers Game," was the use of "big bath" restructuring charges. The reporting requirements and interpretation of restructuring charges have provided a contextual setting of great interest to investors and researchers alike. For example, Elliot and Hanna (1996) address the latitude allowed in applying reporting standards in their study of repeated write-off disclosures. They suggest that as a result of this latitude, firms could classify ordinary operating expenses as non-recurring components of earnings. This classification could artificially increase current and future core earnings and decrease investor reliance on reported earnings numbers that become less interpretable and informative in the presence of unusual items. Former Securities and Exchange Commission (SEC) Chairman Arthur Levitt (1998) expressed the concern that although flexibility in accounting allows it to keep pace with business innovations, it becomes "trickery" when it is used to obscure actual financial volatility.

In 1994, the Emerging Issues Task Force (EITF) of the Financial Accounting Standards Board (FASB) addressed concerns over the reporting of restructuring charges by issuing EITF 94-3, Liability Recognition for Costs to Exit an Activity (Including Certain Costs Incurred in a Restructuring). EITF 94-3 requires, among other things, firms to disclose the disaggregated components of restructuring charges.

Most studies of restructuring charges use data from voluntary footnote disclosures made before the disclosure became mandatory under EITF 94-3. Thus, the results of these studies could be subject to a self-selection bias. ${ }^{1}$ An exception is Lopez (2002), who examines the relation between disaggregated restructuring charges and analysts' earnings forecast revisions. He shows that the components of the restructuring charge are related to analysts' forecast revisions, and thus provide information to analysts beyond the aggregate restructuring charge. Khurana and Lippincott (2000) use pre-mandatory disclosure data to study the effects of firm profit or loss position and reason for restructuring on the relation between restructuring charges and stock returns. They find that the relation between stock returns and restructuring charges differs for profit and loss firms.

Our study builds on the work of Lopez (2002) and Khurana and Lippincott (2000) as follows. First, unlike Lopez (2002), we use stock returns as a measure of the value relevance of disaggregated restructuring charges rather 
than analyst forecast revisions. Second, while Khurana and Lippincott (2000) show that the overall restructuring purpose affects stock returns, we provide evidence that the market regards the disaggregated components of restructuring charges differently. Third, as in Khurana and Lippincott (2000), we provide evidence that suggests a differential effect between restructuring firms that are financially healthy and those that are not. However, we use a measure of financial distress based on Altman's Z and a firm's three-year cumulative income (rather than restructuring year profit or loss), and examine this effect on the relation between returns and the disaggregated restructuring charge (rather than the overall charge.) The study contributes to the body of literature assessing the effect of mandatory footnote disclosure on stock returns.

Similar to Lopez' (2002) findings for analyst forecast revisions, we find significant coefficients on disaggregated components of restructuring charges in a regression of returns on earnings, earnings changes, and restructuring charge components. We provide evidence that for firms that exhibit signs of financial distress, aggregate restructuring charges are priced differently than they are for financially healthy firms. Further, we show that disaggregated components of the restructuring charge are priced differently for financially distressed firms than they are for healthy firms, and that this difference is significant.

The paper is organized as follows. Section 2 presents background information while Section 3 presents a discussion of relevant prior research. We develop hypotheses in Section 4. Section 5 presents the research design and Section 6 discusses sample selection. Section 7 presents results, section 8 summarizes, and section 9 offers suggestions for future research.

\section{Background}

Prior to the issuance of Statement of Financial Accounting Standards (SFAS) No. 146 in 2002, there was no definition of "restructuring" under Generally Accepted Accounting Principles (GAAP). Financial statements across firms showed little consistency in reporting restructuring charges. Practices ranged from including such charges within the components of normal operating expenses to reporting the entire amount net of taxes as an extraordinary item. The SEC sought to reduce the disparity in the financial statement presentation of restructuring charges as increasing numbers of firms undertook such activities. In December 1986, the SEC issued Staff Accounting Bulletin (SAB) No. 67 recommending the recognition and measurement of restructuring charges as a line item within income from continuing operations, and suggesting voluntary footnote disclosure. ${ }^{2}$

Even with the issuance of SAB No. 67, however, companies continued to lack specific guidance for reporting restructuring charges, and as the number of corporate restructurings proliferated, so did disparities in the methods of accounting for, recognizing, and reporting these events. In 1994, the FASB's Emerging Issues Task Force (EITF) addressed this matter in Issue 94-3 (EITF 94-3), Liability Recognition for Costs to Exit an Activity (Including Certain Costs Incurred in a Restructuring).

EITF 94-3 seeks to clarify and provide uniformity in the timing of recognition of the charges, the costs that represent valid charges, and the disclosure of the disaggregated material components of the restructuring charge. Firms are required to recognize restructuring charges at the restructuring commitment date. Required disclosures include the amount of employee termination benefits and exit costs accrued, payments and adjustments to the accrual, and, if material, a description of major actions comprising the exit plan. Exit costs are those that cannot provide any direct future economic benefit to the firm. Such costs are incremental to other costs incurred by the firm prior to the restructuring commitment date and are incurred as a result of the exit plan. SAB No. 100, Restructuring and Impairment Charges (1999) further interprets the requirements of EITF 94-3, and reiterates financial statement disclosure requirements for all periods, including interim periods, until completion of the restructuring plan.

The SEC's increased monitoring and enforcement of the reporting requirements of restructuring charges is an ongoing process, as exemplified by recent SEC enforcement actions against firms using "cookie jar reserves". For example, in March 2002, the SEC settled an administrative action against Kimberly-Clark alleging that the company materially overstated restructuring charges by accruing $\$ 354$ million of merger-related expenses that did 
not constitute restructuring liabilities under GAAP as of December 31, 1995. Further, the SEC found that between 1996 and 1998, the company failed to account for certain liabilities associated with the total 1995 charge of $\$ 1.44$ billion. In August 1999, Kimberly-Clark voluntarily restated its financial statements for 1995, 1996, 1997, 1998, and the first quarter of 1999 .

In spite of stricter enforcement actions and reporting requirements, the relative merits of EITF 94-3 continue to be questioned among SEC officials and members of the financial community. In 1999, Walter Scheutze, Chief Accountant of the SEC Division of Enforcement voiced concerns about reporting practices as follows:

Analysts seem to like the idea of recognizing as a liability today, a budget of expenditures planned for the next year or next several years in downsizing, right-sizing, or improving operations.... This year's earnings are happily reported in press releases as 'before charges.' ... [Since 1994] general reserves, contingency reserves, rainy day reserves, and cookie jar reserves, now are in vogue for those who want to use them... there apparently is almost no limit to what ingredient may be included in the reserves or the amount ascribed to it.... the numbers ascribed to restructurings and thus included in the reserves cannot be verified by the outside auditor by reference to anything except management's assertion... Moreover, I have seen the amounts of those initially established reserves arbitrarily increased for good measure. These excessive amounts of reserves then are leeched, undisclosed, into subsequent operating income, at a rate that is under someone's radar screen of materiality.

In June 2002, the FASB issued SFAS No. 146, Accounting for Costs Associated with Exit or Disposal Activities. ${ }^{3}$ The statement retains the financial statement presentation and footnote disclosure requirements of EITF 943 and SAB No. 100. However, under SFAS No. 146, the restructuring commitment date is no longer the time of liability recognition. Restructuring charges are recorded when the amounts meet the recognition criteria under SFAS No. 5- that is, when the amounts are probable and can be reasonably estimated. Thus, SFAS No. 146 reiterates the usefulness of the existing disclosure requirements under EITF 94-3, while explicitly redefining the appropriate timing for recognition of restructuring charges.

\section{Prior Research}

Leuz and Verrecchia (2000) suggest that increased levels of disclosure reduce information asymmetries and are significantly related to lower costs of capital. They examine 102 German firms that switched to higherdisclosure International Accounting Standards (IAS) or U.S. GAAP for their consolidated financial statements. Results suggest that trading volume as a measure of liquidity increases with the adoption of new reporting standards, but that stock price volatility is not significantly related to the switch.

Barth et al. (1992) present evidence that investors price the disclosed components of pension costs and other post-retirement benefits differently than they price the aggregate amount. They examine pension cost components disclosed in footnotes under SFAS No. 87 and find that the coefficients on these components are priced differently from one another. Further, they show that the transitory cost component, deferred return on assets, had a smaller coefficient than did more permanent costs components (i.e., realized return on plan assets, service cost, and interest cost).

Several empirical studies have examined the announcement effects of restructuring charges in total and disaggregated by the types of costs typically associated with a pre-EITF 94-3 corporate restructuring. The disaggregate components have either been voluntarily disclosed or have been determined by the researcher based on available information. In their study of abnormal returns and pre-EITF 94-3 restructuring charges, Hogan and Jeter (1998) find that the market reacts negatively to severance charges when there has been a recent management change and a current period loss, but reacts positively otherwise. For asset write-offs, they find a positive coefficient when there has been a recent management change and a current period loss. Thus, the market seems influenced by management's incentives related to the restructuring charge.

Kross et al. (1998) use pre-EITF 94-3 data to investigate the association between restructuring components and positive announcement period returns, and examine the effect of asset disposals, plant closing and relocations, 
asset writedowns, and employee terminations on returns. They find a positive and significant effect only between two-day announcement period abnormal returns and asset disposals. Blackwell et al. (1990) propose that a plant closing should increase firm value if the present value of expected cash benefits exceeds the discounted value of future cash flows from the plant. They find that abnormal returns are negative for plant closing announcements, and argue that the effect may be a result not of the plant closing, but of underlying reduced demand or declining profitability that caused managers to close the plant.

Iqbal and Shetty (1991) find that investors generally perceive layoffs as unfavorable events that generate negative stock returns. However, in a later study, Iqbal and Akhigbe (1997) find that firms show improvements in operating cash flows following layoffs. Their analysis of stock price reactions to layoff announcements suggests that abnormal returns are negative and significant for firms who lay off employees in response to weak financial conditions without providing favorable information about expected future operating performance. Conversely, firms announcing layoffs as a means to improve operating performance experience significant and positive abnormal stock returns.

Francis et al. (1996) report significant negative returns for asset write-downs, but a positive relation between returns and restructuring charges. They suggest that inventory write-downs are driven by impairment forces (declines in economic value), while restructuring charges are seen as a signal by management of future improved firm performance.

Khurana and Lippincott (2000) use pre-EITF 94-3 data to examine the earnings-return relation during the restructuring year for firms that both announced and underwent a restructuring during the period 1984 to 1994. They find no significant contemporaneous association between the aggregate charge and return for the full sample. When they partition their sample firms by restructuring year profit or loss, however, they find a significant positive association between restructuring charges and returns for loss firms only, and a significant negative association for profit firms. When they again partition their sample based on their determination of primary restructuring purpose (i.e. termination, exit, or other), they find that the restructuring charge is significantly negative for profit firms only when the primary purpose of the restructuring is not disclosed, while it is positive and significantly associated with stock prices for loss firms when the purpose is disclosed, and not significant otherwise. They suggest that investors view restructuring as a value-increasing action for loss firms unless the primary purpose of the restructuring is unclear.

Lopez (2002) is among the first researchers to examine the effects of EITF-94 disclosure requirements by using financial statements containing the disaggregated components of the charge for operational restructurings. His results suggest that components of the charge are incorporated into analysts' forecast revisions; therefore they contain value-relevant information, incremental to the information contained in the aggregate charge

\section{Hypothesis Development}

Corporate restructuring activities encompass a number of different components, each with potentially different implications for future cash flows. It is thus left to the user of this information to assess whether or not the restructuring will improve firm performance, and if so, to what extent. For example, costs related to involuntary employee terminations could reduce cash flow in the short-term as a result of severance payments, the settlement of benefit obligations, and outplacement efforts. However, in the long-term, the firm may recognize net increased cash flows to the extent that the cost reduction exceeds the revenues that were generated by these employees. Contract terminations and exit costs generally result in cash outflows with increased future inflows as a result of the cost reduction. Asset writedowns, as accounting adjustments, have no immediate cash flow implications. But they should reflect lower future cash flows (revenue-generating ability) than was suggested by their book values prior to the writedown, so could be viewed negatively by investors. However, Hogan and Jeter (1998) suggest that if the writedown is perceived as management's commitment to redirect efforts toward more profitable investments, the writedown could be viewed positively. Facility closings could signal bad news about investment opportunities or expected cash flows, or underlying declines in demand or profitability (Lopez, 2002). However, if the discounted 
value of expected cash flows from the facility is less than the present value of expected benefits from the closing, firm value would be increased (Blackwell et al. 1990).

If the disaggregation of restructuring charges improves their decision-usefulness, then disaggregated charges, isolated from the other components of operating earnings, will be more value relevant than the aggregated charge (Lopez, 2002). Our first hypothesis, stated in the alternative, is:

H1: The components of restructuring charges have explanatory power for returns beyond that contained in the aggregate charge.

Hayn (1995) suggests that losses are less persistent than profits and are less value-relevant, since shareholders have the option to liquidate the firm. If investors perceive a future improvement in operating performance for the loss firm, rather than a potential liquidation, restructuring charges could increase the explanatory power of earnings for returns. Khurana and Lippincott (2000) show that, conditioned on their determination of primary restructuring purpose, the relation between returns and voluntarily disclosed restructuring charges is different for loss firms than for profit firms in the restructuring year. They interpret their results to mean that investors perceive restructuring as a positive, value-enhancing activity for loss firms, conditioned on the clarity of the financial statement disclosure.

Current year operating performance may be perceived as one measure of a firm's potential for liquidation, but there are a number of other characteristics to be considered when assessing a firm's financial strength or weakness. While an operating loss may be viewed as temporary (Hayn 1995), a continual decline in operating performance will contribute to a decline on such dimensions as liquidity and solvency. For firms that exhibit signs of financial distress, investors may perceive an operational restructuring as either a positive, performance-enhancing event moving a firm further from its distressed condition, or alternatively, as a negative event precursory to impending doom. Moreover, the components of a restructuring charge, which provide detail as to the specific actions that the firm has taken, may be interpreted differently for distressed firms than for healthy firms. This leads to the following hypotheses:

H2(a): For financially distressed firms, restructuring charges will exhibit a positive relation to returns.

H2(b): The relation of the disaggregated components of restructuring charges to returns will differ between financially distressed firms and healthy firms.

\section{Research Design}

For our preliminary analysis, we segregate the restructuring charge from the aggregate measure of recurring earnings and employ a returns model similar to that used in Khurana and Lippincott (2000), adapted from the Easton and Harris (1991) approach of regressing contemporaneous returns on earnings levels and earnings changes.

$R_{\mathrm{i}, \mathrm{t}}=\gamma_{0}+\gamma_{1}\left(N E_{\mathrm{i}, \mathrm{t}} / M V E_{\mathrm{i}, \mathrm{t}-1}\right)+\gamma_{2}\left(\Delta N E_{\mathrm{i}, \mathrm{t}} / M V E_{\mathrm{i}, \mathrm{t}-1}\right)+e_{\mathrm{i}, \mathrm{t}}$

where $\mathrm{Ri}, \mathrm{t}$ is the annual return for firm $\mathrm{i}$ at time t, NE is pretax net operating earnings excluding the restructuring charge, and $\triangle \mathrm{NE}$ is the change in NE over the fiscal year. Explanatory variable are scaled by MVE, the market value of equity at the beginning of the fiscal year. Coefficients are predicted to be positive. Consistent with Khurana and Lippincott (2000), returns are measured three months after the fiscal year end. We add the restructuring charge to the equation as follows:

$R_{\mathrm{i}, \mathrm{t}}=\gamma_{0}+\gamma_{1}\left(N E_{\mathrm{i}, \mathrm{l}} / M V E_{\mathrm{i}, \mathrm{t}-1}\right)+\gamma_{2}\left(\Delta N E_{\mathrm{i}, \mathrm{l}} / M V E_{\mathrm{i},-1-1}\right)+\gamma_{3}\left(R E S T R U C T_{\mathrm{i}, l} / M V E_{\mathrm{i}, \mathrm{t}-1}\right)+e_{\mathrm{i}, \mathrm{t}}$

where RESTRUCT is the pretax restructuring charge. RESTRUCT enters the equation as a negative value.

Elliott and Hanna (1996) show that repeated accounting write-offs reduce the emphasis that investors place on earnings in firm valuation. Additionally, firms recording restructuring charges often reverse the accrual in 
subsequent periods, creating a "negative restructuring charge" that increases income (Moehrle, 2002). This reversal appears either as an identifiable line item, or as a reduction to current year restructuring charges. Khurana and Lippincott (2000) suggest that prior year restructurings did not occur for most firms in their study, however Lopez (2002) finds that 57 of his 190 firm-year observations were recurring items. He shows that the relation of analysts' earnings forecast revisions to restructuring charges absent the recurring charge firms was strengthened. Moreover, restructuring charges taken prior to the mandates of EITF 94-3 are often aggregated, and it is not possible in many cases to identify the separate components of the previous charge or to identify the specific component that was subsequently adjusted due to prior charge reversal. Thus, we eliminate from the sample firms that reported a restructuring charge in the preceding year.

Tests of H1 require that the restructuring charges in Eq. (1b) be disaggregated into their separate components. To test whether the disaggregated components have an effect on firm value, the restructuring charges in Eq. (1b) are decomposed as follows:

$$
\begin{aligned}
R_{\mathrm{i}, \mathrm{t}} & =\gamma_{0}+\gamma_{1}\left(N E_{\mathrm{i}, t} / M V E_{\mathrm{i}, \mathrm{t}-1}\right)+\gamma_{2}\left(\Delta N E_{\mathrm{i}, \mathrm{t}} / M V E_{\mathrm{i}, \mathrm{t}-1}\right)+\gamma_{3}\left(T E R M_{\mathrm{i}, \mathrm{t}} / M V E_{\mathrm{i}, \mathrm{t}-1}\right)+\gamma_{4}\left(E X I T_{\mathrm{i}, \mathrm{l}} / M V E_{\mathrm{i}, \mathrm{t}-1}\right) \\
& +\gamma_{5}\left(\operatorname{CLOSE} E_{\mathrm{i}, \mathrm{l}} / M V E_{\mathrm{i}, \mathrm{t}-1}\right)+\gamma_{6}\left(W D N_{\mathrm{i}, \mathrm{l}} / M V E_{\mathrm{i}, \mathrm{t}-1}\right)+\gamma_{7}\left(U N C L_{\mathrm{i}, \mathrm{t}} / M V E_{\mathrm{i}, \mathrm{t}-1}\right)+e_{\mathrm{i}, \mathrm{t}}
\end{aligned}
$$

where TERM is employee severance and termination benefits, EXIT is miscellaneous exit costs, CLOSE is plant and facility closings, WDN is asset writedowns, and UNCL is an amount representing charges not otherwise classified.

Rather than being an aggregate measure of restructuring charge components that should be otherwise categorized (such as terminations and closings), UNCL represents information supplemental to other disclosures. Disclosures in this category tend to be made by firms that disclose two or more restructuring charge components, so $U N C L$ represents a higher level of disclosure rather than a lower level. We add to this category specific disclosures for contract terminations, lease terminations, and legal fees, which were comparatively small and infrequent disclosures. Firms that use this category to net all regular components of restructuring charges (so that $U N C L$ equals the total restructuring charge), are deemed to be noncompliant with the requirements of EITF 94-3, and are not included in the study. Consistent with Lopez (2002), we make no prediction on the signs of the coefficients. Depending on which components make up the aggregate charge for the firm, the relative proportion of each component to the aggregate charge, and classification differences that occur among firms, the responses are difficult to predict. The preceding may have contributed to the mixed findings in previously cited restructuring and writedown studies.

Tests of $\mathrm{H} 2$ (a) and $\mathrm{H} 2$ (b) require segregation of the sample into financially healthy and financially distressed firms. Consistent with prior research, we choose Altman's Z-score as our first measure of financial distress. A firm that achieves a Z-score of 1.81 or less is considered to have a high probability of bankruptcy. Altman (2002) tests his Z-score over three continuous time periods from 1969 to 1999 . He finds that the potential to classify a healthy firm as distressed has increased over time, with as many as $15-20 \%$ of his sample firms and $10 \%$ of his largest sample firms being incorrectly classified as having a high probability of bankruptcy using the 1.81 cutoff, a Type II error (Altman, 2002). To overcome this potential limitation, we choose an additional measure of financial distress adapted from the measure suggested by Andes et al. (1996). This measure defines financially distressed firms as those having cumulative negative earnings over a three-year operating period. The two measures are combined to mitigate the possibility of a Type II classification error. We define a financially healthy firm as any firm with a Z-score over 1.81, or that generated both (1) positive lagged cumulative operating income (LCOI), and (2) current cumulative operating income in excess of LCOI, regardless of $\mathrm{Z}$ score. ${ }^{4}$ Any firm not meeting these criteria was classified as "financially distressed."

We add to the previous equations an indicator variable FD that takes on the value of one if a firm has been classified as financially distressed and zero otherwise. This variable is interacted with aggregated and disaggregated restructuring charges. Eq. 1(b) is expanded as follows to test $\mathrm{H} 2(\mathrm{a})$ : 


$$
\begin{aligned}
R_{\mathrm{i}, \mathrm{t}} & =\gamma_{0}+\gamma_{1}\left(N E_{\mathrm{i}, l} / M V E_{\mathrm{i}, \mathrm{t}-1}\right)+\gamma_{2}\left(\Delta N E_{\mathrm{i}, l} / M V E_{\mathrm{i}, t-1}+\gamma_{3} F D_{\mathrm{i}, \mathrm{t}}+\gamma_{4}\left(R E S T R U C T_{\mathrm{i}, t} / M V E_{\mathrm{i}, \mathrm{t}-1}\right)\right. \\
& +\square \gamma_{5} F D *\left(\operatorname{RESTRUCT} T_{\mathrm{i}, l}\left(M V E_{\mathrm{i}, \mathrm{t}-1}\right)+e_{\mathrm{i}, \mathrm{t}}\right.
\end{aligned}
$$

Eq. 2 is expanded to test $\mathrm{H} 2(\mathrm{~b})$ :

$$
\begin{aligned}
R_{\mathrm{i}, \mathrm{t}} & =\gamma_{0}+\gamma_{1}\left(N E_{\mathrm{i}, \mathrm{t}} / M V E_{\mathrm{i}, \mathrm{t}-1}\right)+\gamma_{2}\left(\Delta N E_{\mathrm{i}, \mathrm{l}} / M V E_{\mathrm{i}, \mathrm{t}-1}\right)+\gamma_{3} F D_{\mathrm{i}, \mathrm{t}}+\gamma_{4}\left(T E R M_{\mathrm{i}, \mathrm{l}} / M V E_{\mathrm{i}, \mathrm{t}-1}\right)+\gamma_{5} F D^{*}\left(T E R M_{\mathrm{i}, \mathrm{l}} / M V E_{\mathrm{i}, \mathrm{t}-1}\right) \\
& +\gamma_{6}\left(E X I T_{\mathrm{i}, \mathrm{t}} / M V E_{\mathrm{i}, \mathrm{t}-1}\right)+\gamma_{7} F D^{*}\left(E X I T_{\mathrm{i}, \mathrm{t}} / M V E_{\mathrm{i}, \mathrm{t}-1}\right)+\gamma_{8}\left(C L O S E_{\mathrm{i}, \mathrm{l}} M V E_{\mathrm{i}, \mathrm{t}-1}\right)+\gamma_{9} F D^{*}\left(C L O S E_{\mathrm{i}, \mathrm{t}} / M V E_{\mathrm{i}, \mathrm{t}-1}\right) \\
& +\gamma_{10}\left(W D N_{\mathrm{i}, \mathrm{t}} / M V E_{\mathrm{i}, \mathrm{t}-1}\right)+\gamma_{11} F D^{*}\left(W D N_{\mathrm{i}, \mathrm{t}} / M V E_{\mathrm{i}, \mathrm{t}-1}\right)+\gamma_{12}\left(U N C L_{\mathrm{i}, \mathrm{t}} / M V E_{\mathrm{i}, \mathrm{t}-1}\right)+\gamma_{14} F D^{*}\left(U N C L_{\mathrm{i}, \mathrm{t}} / M V E_{\mathrm{i}, \mathrm{t}-1}\right) \\
& +e_{\mathrm{i}, \mathrm{t}}
\end{aligned}
$$

\section{Sample Selection And Descriptive Statistics}

The sample is limited to firms undergoing operational restructurings, subject to the requirements of EITF 94-3 for the first year that the disclosure was mandatory, and traded on the NYSE, AMEX, or Nasdaq. The sample was obtained by reviewing firm restructuring announcements for the period January, 1995 through June, 1996 from the Lexis-Nexis Academic Universe Electronic Database. We eliminate announcements that do not fit the definition of an operational restructuring (e.g., mergers and divestitures, debt restructurings) and those that refer only to restructurings that occurred in prior periods. Financial services companies and utility companies are eliminated due to the regulatory environments unique to these types of firms. Announcements are traced to available 10-Ks by using the SEC's 10-K Wizard database.

We review the 10-Ks for the announcing firms for normal operating expenses on the income statement that are identified as "restructuring," "reorganization," "realignment, "non-recurring," or "special." We then read the related footnotes, or, in the absence of identifiable restructuring charges on the income statement, review the footnotes alone for disclosure of any such charges that may be included in income from continuing operations. Sample footnotes are shown in Appendix A. To be included in the sample, firms must have financial information for 1994, 1995, and 1996 on Standard and Poor's Compustat annual database and stock prices available from the University of Chicago's Center for Research in Security Prices (CRSP). Firms are matched to the databases by CUSIP number. The final sample consists of 116 firms that announced and reported restructuring charges for fiscal years ending June 30, 1995 through December 31, 1996. This is comparable to Lopez (2002), whose study of disaggregated restructuring charges consisted of a sample of 103 and 87 firm-year observations for the periods 1994-1995 and 1996-1997, respectively (153 firms). Table 1 presents a sample attrition schedule, including the disaggregated disclosure characteristics for sample firms.

Descriptive statistics for the full sample are presented in Table 2. The sample consists predominantly of smaller firms with mean (median) assets of $\$ 2,614.71$ (\$353.93) million and mean (median) market value of equity of $\$ 2,946.47$ ( $\$ 145.25$ ) million. The sample exhibits similar skewness to the 10-year, 299-firm sample used by Khurana and Lippincott (2000), and to the 4-year, 153-firm sample examined by Lopez (2002), however, the firms in our study are smaller on average. The Khurana and Lippincott (2000) sample consists of voluntary disclosure firms. Our sample is subject to mandatory disclosure under EITF 94-3 regardless of size or operating results, and may include smaller firms that may have not disclosed the restructuring charge absent the mandate. Lopez (2002) requires analyst information from the Value Line Investment Survey for his sample, which could eliminate the smallest reporting firms from his study.

Sample firms experienced a median net loss of $\$ 4.04$ million, and a mean net income of $\$ 13.14$ million. Mean (median) adjusted operating income (operating income excluding restructuring charges, or "AOI") indicates an overall operating profit of $\$ 289.34$ (\$11.23) million, however sample firms experienced a median decrease of $\$ 2.68$ million from the previous fiscal year in this area. The overall mean (median) restructuring charge is $\$ 117.48$ (\$11.65) million, similar to that reported by Khurana and Lippincott (2000). Overall, the mean (median) ratio of the restructuring charge to the market value of equity for our sample is $11.59 \%$ (4.37\%), generally consistent with the same levels reported by Khurana and Lippincott (2000) and Lopez (2002). Additional analysis (results not tabulated) indicates that of the 116 sample firms, 33 generated operating losses excluding restructuring charges for the period, and 83 generated profits. The restructuring charge resulted in an overall operating loss for 23 of the 83 profit firms. 
Table 1: Sample

\begin{tabular}{lr}
\hline Panel A: Sample selection & \\
\hline Total restructuring announcements from January 1995 through June 1996 from the Lexis-Nexis Acdemic & 323 \\
Universe Electronic Database & $(90)$ \\
Financial firms and merger announcements & $(13)$ \\
Firms not filing SEC Form 10-K & $(7)$ \\
Firms not reporting restructuring charges on SEC Form 10-K & $(52)$ \\
Firms not listed on NYSE, AMEX, or Nasdaq & $(4)$ \\
Firms that did not match both Compustat and CRSP databases & 157 \\
$\quad$ Subtotal & $(21)$ \\
Firms with restructuring charges in prior year & $(3)$ \\
Firms with positive restructuring charges & $(10)$ \\
Firms that did not disaggregate charges & $(5)$ \\
Firms missing financial information & $(2)$ \\
Outliers $\quad$ Final Sample & 116 \\
\hline Panel B: Types and combinations of disaggregated restructuring charge disclosures & 18 \\
\hline Termination costs only & 5 \\
Adjusted exit costs only & 7 \\
Facility closing only & 1 \\
Writedown only & \\
Termination costs and other disclosures*, including facility closing & 32 \\
Termination costs and other disclosures, without facility closing & 38 \\
Facility closing and other disclosures, with no termination costs & 7 \\
All other combinations of disclosure, with no termination costs or facility closing & 116 \\
\hline
\end{tabular}

* Other disclosures include adjusted exit costs, asset writedowns, and other disclosures not fitting into these categories.

Table 2: Descriptive Statistics For Full Sample

\begin{tabular}{|c|c|c|c|c|c|c|}
\hline & & Minimum & Median & Mean & Maximum & Std Dev \\
\hline \multicolumn{7}{|l|}{$n=116$} \\
\hline Assets (\$Mil) & & 11.531 & 353.934 & $2,614.708$ & $88,884.000$ & $9,110.567$ \\
\hline Market Value of Equity (\$Mil) & & 11.706 & 145.252 & $2,946.468$ & $103,082.000$ & $11,310.638$ \\
\hline Book Value of Equity ( $\$$ Mil) & & -351.645 & 110.764 & 765.932 & $17,274.000$ & $2,130.746$ \\
\hline Book to Market & & -0.629 & 0.563 & 0.655 & 2.911 & 0.507 \\
\hline Debt to Equity & & -18.065 & 1.447 & 2.167 & 27.853 & 4.651 \\
\hline Return on Assets & & -0.950 & -0.021 & -0.070 & 0.136 & 0.165 \\
\hline Net Income (\$Mil) & & $-1,232.000$ & -4.037 & 13.138 & $1,812.000$ & 233.838 \\
\hline Adjusted Operating Inc.(AOI)* (\$Mil) & & -113.977 & 11.233 & 289.340 & $10,109.000$ & $1,105.486$ \\
\hline Change in AOI (\$Mil) & & -405.000 & -2.677 & 17.545 & $1,108.000$ & 164.008 \\
\hline Restructuring (\$Mil) & & 0.150 & 11.650 & 117.484 & $5,336.000$ & 527.598 \\
\hline Restructuring/Net Income & & -23.488 & -0.145 & 0.729 & 43.374 & 6.486 \\
\hline Restructuring/AOI & & -38.400 & 0.207 & 0.527 & 100.606 & 10.755 \\
\hline \multicolumn{7}{|l|}{ Disaggregated Restructuring Charges: } \\
\hline Termination (\$Mil) & $\mathrm{n}=88$ & 0.100 & 3.600 & 92.568 & $5,336.000$ & 578.707 \\
\hline Exit (\$Mil) & $\mathrm{n}=11$ & 2.200 & 6.700 & 9.118 & 33.900 & 9.354 \\
\hline Writedowns (\$Mil) & $\mathrm{n}=55$ & 0.100 & 8.300 & 34.828 & 293.000 & 64.207 \\
\hline Facility Closings (\$Mil) & $\mathrm{n}=46$ & 0.100 & 6.325 & 31.319 & 211.800 & 57.070 \\
\hline Unclassified, Misc. (\$Mil) & $\mathrm{n}=30$ & 0.100 & 2.450 & 58.070 & 930.700 & 188.380 \\
\hline Termination/AOI & $\mathrm{n}=88$ & -12.800 & 0.067 & 0.428 & 26.275 & 3.968 \\
\hline Exit/AOI & $\mathrm{n}=11$ & -18.400 & 0.156 & -1.177 & 2.813 & 5.801 \\
\hline Writedowns/AOI & $\mathrm{n}=55$ & -7.200 & 0.097 & 0.456 & 42.424 & 6.022 \\
\hline Facility Closings/AOI & $n=46$ & -24.785 & 0.103 & -0.643 & 0.959 & 3.933 \\
\hline Unclassified/AOI & $\mathrm{n}=30$ & -0.625 & 0.034 & 0.057 & 0.880 & 0.329 \\
\hline
\end{tabular}


Termination costs are reported by 88 of the 116 firms (76\%), and represent an average of $62 \%$ of total restructuring charges for the full sample. Panel B of Table 1 indicates that 18 of these termination events occurred in isolation, 32 were terminations disclosed specifically with facility closings, and 38 were disclosed with non-closing components of restructuring charges. Of the 46 disclosed facility closings, seven were disclosed in isolation, and seven were disclosed in conjunction with non-termination charges. Writedowns and exit costs are reported by $49 \%$ and $10 \%$ of reporting firms, respectively, and each represented approximately $15 \%$ of total restructuring charges overall. Disclosures not classified in any of the preceding categories are presented by 30 of the sample firms. These disclosures are supplemental to other disaggregated disclosures for firms using this category, thus represent a higher level of disclosure rather than a lower level.

Table 3 presents comparative descriptive statistics by distress category. In general, while both distressed and healthy firms are small, the firms classified as healthy are the larger of the two groups, as indicated by the median values of assets, market value of equity, and book value of equity. Mean and median restructuring charges, by component and in the aggregate, are smaller for distressed firms than for healthy firms. This relation holds for both the size of the component of the charge and for its relationship to AOI. While healthy firms reported more disclosures in each category, the proportion of reporting firms was smaller for healthy firms, except for facility closings and unclassified (additional) disclosures. Z statistics generated as a result of the Wilcoxon Rank Sum Test of equal means indicate that for most measures, the difference between healthy and distressed firms is significant at conventional levels.

Altman's Z-score model as the singular measure of financial distress tended to misclassify many of the sample firms (mean and median Z-scores for healthy firms 1.76 and 1.68, respectively). Additional measures of financial distress, cumulative and lagged three-year cumulative operating income are presented to demonstrate the significant differences in operating performance between the two groups. ${ }^{5}$

\section{Empirical results}

We present results of our estimation of equations 1(a) and 1(b) in Panels A and B of Table 4. Consistent with prior research, operating income and the change in operating income are positively and significantly related to returns. The addition of RESTRUCT to the existing components of operating income indicates that the aggregate charge overall is not significant in explaining returns, and decreases the explanatory power of the model slightly from 0.282 to 0.277 .

Panel C presents results for estimation of equation 2. Disaggregating the components of the restructuring charge increases the overall explanatory power of the equation for returns, as reflected in an increased adjusted $\mathrm{R}^{2}$ of 0.303 . While the aggregate restructuring charge was not significantly related to returns, the components comprising the charge exhibit a different relation. The coefficient on TERM is negative and significant $(|t|=1.74, p=0.085)$, indicating that investors perceive employee terminations as value-enhancing events. This is consistent with Iqbal and Akhigbe (1997), who suggest that investors view employee terminations positively when the stated purpose of the termination is to improve operating efficiency, as in a restructuring, rather than as a response to a declining financial position.

The coefficient on WDN is also negative and significant $(|t|=1.67, p=0.098)$, indicating that the writedown has a positive effect on returns. This is consistent with the result obtained by Lopez (2002) for one-year ahead analyst forecast revisions. Lopez (2002) attributes this result in part to the acceleration of future depreciation expense into current earnings. Thus, although the writedown is a noncash expense, future operating earnings will be increased as a result of decreased future depreciation expense. Moreover, Wilson (1996) suggests that the examination of write-offs is complicated by factors including different market reactions to different types of write-offs, industry conditions, or firm-specific events that may affect write-off decisions. When a firm undergoes an operational restructuring, the writedown is no longer an isolated accounting adjustment, but part of an overall strategy undertaken to improve operating performance. Writedowns can occur as a result of closing facilities, consolidating operations, or in recognition of the declining operating efficiency of the asset. Within the restructuring context, it would not be inconsistent with investors' perceptions of improved future operating performance, as suggested by 
Table 3: Descriptive Statistics By Distress Category

\begin{tabular}{|c|c|c|c|c|c|c|c|c|c|c|c|}
\hline \multirow[t]{2}{*}{$\begin{array}{ll}\text { Distressed Firms: } & \mathrm{n}=50 \\
\text { Healthy Firms: } & \mathrm{n}=66 \\
\end{array}$} & \multicolumn{4}{|c|}{ Minimum } & \multicolumn{2}{|c|}{ Median } & \multicolumn{2}{|c|}{ Mean } & \multicolumn{2}{|c|}{ Maximum } & \multirow[b]{3}{*}{$* * *$} \\
\hline & & Distressed & & Healthy & Distressed & Healthy & Distressed & Healthy & Distressed & Healthy & \\
\hline Assets (\$Mil) & & 15.890 & & 11.531 & 173.705 & 549.809 & 550.322 & $4,178.637$ & $3,358.200$ & $88,884.000$ & \\
\hline Market Value of Equity (\$Mil) & & 11.706 & & 14.631 & 94.723 & 325.280 & 574.388 & $4,743.499$ & $8,196.250$ & $103,082.000$ & $* * *$ \\
\hline Book Value of Equity (\$Mil) & & -351.645 & & -0.734 & 41.088 & 181.067 & 173.624 & $1,214.649$ & 929.300 & $17,274.000$ & $* * *$ \\
\hline Book to Market & & -0.629 & & -0.045 & 0.682 & 0.527 & 0.719 & 0.607 & 2.031 & 2.911 & \\
\hline Debt to Equity & & -10.897 & & -18.065 & 1.192 & 1.809 & 2.141 & 2.186 & 27.853 & 16.074 & $* *$ \\
\hline Return on Assets & & -0.950 & & -0.786 & -0.053 & 0.002 & -0.108 & -0.041 & 0.086 & 0.136 & $* * *$ \\
\hline Net Income (\$Mil) & & -512.463 & & $-1,232.000$ & -7.270 & 1.539 & -21.459 & 39.348 & 367.400 & $1,812.000$ & $* * *$ \\
\hline Adj. Oper. Inc.(AOI) (\$Mil) & & -113.977 & & -64.273 & 0.191 & 28.015 & 23.448 & 490.774 & 689.000 & $10,109.000$ & $* * *$ \\
\hline Change in AOI (\$Mil) & & -310.400 & & -405.000 & -6.016 & 2.769 & -25.069 & 49.828 & 68.577 & $1,108.000$ & $* * *$ \\
\hline Restructuring (\$Mil) & & 0.200 & & 0.150 & 5.050 & 18.950 & 20.491 & 190.963 & 183.200 & $5,336.000$ & $* * *$ \\
\hline Restructuring/Net Income & & -2.974 & & -23.488 & -0.297 & 0.059 & 0.234 & 1.104 & 15.430 & 43.374 & \\
\hline Restructuring/AOI & & -38.400 & & -24.785 & 0.066 & 0.268 & 1.397 & -0.132 & 100.606 & 4.520 & $* *$ \\
\hline Disaggregated Restructuring Chg & $\mathbf{n}$ & & $\mathbf{n}$ & & & & & & & & \\
\hline Termination (\$Mil) & 39 & 0.200 & 49 & 0.100 & 2.400 & 5.300 & 5.343 & 161.992 & 27.800 & $5,336.000$ & $* *$ \\
\hline Exit (\$Mil) & 5 & 2.200 & 6 & 4.100 & 3.800 & 8.050 & 4.240 & 13.183 & 7.700 & 33.900 & $*$ \\
\hline Writedowns (\$Mil) & 27 & 0.300 & 28 & 0.100 & 4.500 & 15.400 & 18.162 & 50.900 & 139.000 & 293.000 & $* *$ \\
\hline Facility Closings (\$Mil) & 16 & 0.100 & 30 & 0.240 & 2.800 & 7.950 & 8.961 & 43.243 & 44.200 & 211.800 & $* *$ \\
\hline Unclassified, Misc. (\$Mil) & 11 & 0.100 & 19 & 0.100 & 1.200 & 3.300 & 5.940 & 88.240 & 45.300 & 930.700 & \\
\hline Termination/AOI & 39 & -12.800 & 49 & -1.163 & 0.040 & 0.084 & 0.848 & 0.095 & 26.275 & 0.708 & $*$ \\
\hline Exit/AOI & 5 & -18.400 & 6 & 0.060 & 0.156 & 0.369 & -3.696 & 0.922 & 0.530 & 2.813 & \\
\hline Writedowns/AOI & 27 & -7.200 & 28 & -2.927 & -0.041 & 0.118 & 0.732 & 0.190 & 42.424 & 2.544 & \\
\hline Facility Closings/AOI & 16 & -1.542 & 30 & -24.785 & -0.006 & 0.122 & -0.110 & -0.928 & 0.959 & 0.813 & $* *$ \\
\hline Unclassified/AOI & 11 & -0.625 & 19 & -0.570 & 0.005 & 0.060 & -0.033 & 0.109 & 0.880 & 0.658 & \\
\hline \multicolumn{12}{|l|}{ Distress Measures } \\
\hline Altman's Z & & 0.384 & & 0.423 & 1.354 & 1.677 & 1.320 & 1.764 & 2.234 & 5.238 & $* * *$ \\
\hline Lagged 3-Year Cumulative Op. Inc. & & -242.500 & & 0.919 & 31.270 & 98.640 & 163.420 & $1,108.520$ & $2,886.700$ & $22,576.000$ & $* * *$ \\
\hline 3-Year Cumulative Op. Inc. & & -217.630 & & -44.342 & 15.790 & 105.810 & 123.010 & $1,292.420$ & $2,673.000$ & $26,352.000$ & $* * *$ \\
\hline
\end{tabular}


Table 4: Cross-Sectional Regressions Of Annual Stock Returns

On Operating Income, Change In Operating Income, And Restructuring Charges:

Excludes Firms With Prior Year Restructuring Charge

$R_{\mathrm{i}, \mathrm{t}}=\gamma_{0}+\gamma_{1} N E+\gamma_{2} \square N E+\gamma_{3} F D_{\mathrm{i}, \mathrm{t}}+\gamma_{4} T E R M+\gamma_{5} F D^{*} T E R M+\gamma_{6} E X I T+\gamma_{7} F D^{*} E X I T+\gamma_{8} C L O S E+\gamma_{9} D^{*} C L O S E+\gamma$
${ }_{10} W D N+\gamma_{11} F D^{*} W D N+\gamma_{12} U N C L+\gamma_{14} F D^{*} U N C L+e$

All independent variables except the indicator variable $F D$ are scaled by $M V E_{t-1}$

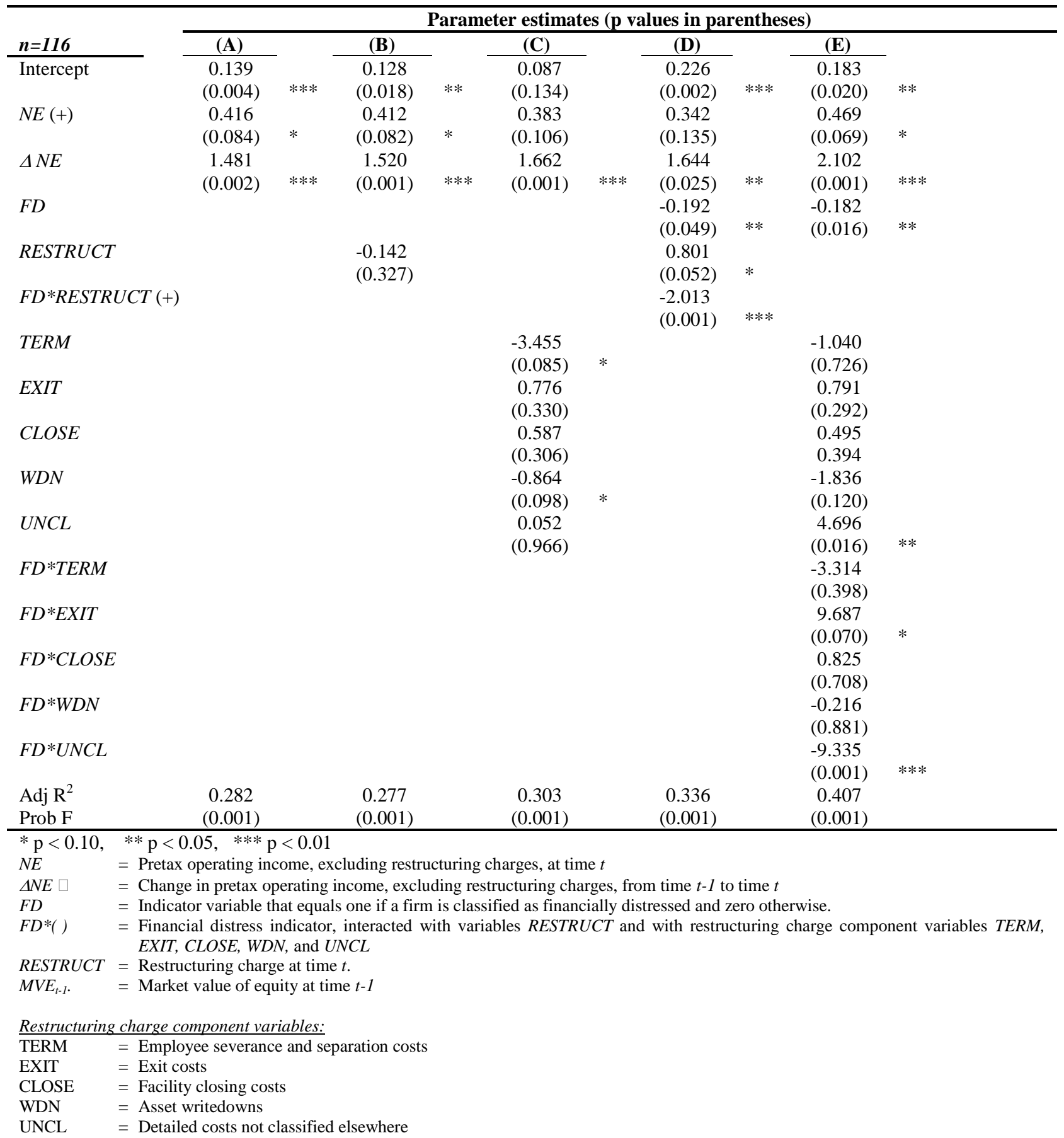


Hogan and Jeter (1998), to view such writedowns as positive events. The positive and significant effects of these two disclosures suggest that disaggregation of the restructuring charges provides information incremental to that provided by the aggregate charge, and these results support $\mathrm{H} 1$.

Panel D reports the results of estimating equation (3). The inclusion of FD as an indicator variable and as an interaction term with RESTRUCT increases the adjusted $R^{2}$ to 0.336 . The variable itself is significant in the model ( $\mathrm{p}$ value of 0.049), indicating an overall negative impact on returns for financially distressed firms. The negative coefficient on the interaction term FDRESTRUCT is significant at $p=0.001$. Combining the two restructuring estimated coefficients, the effect of restructuring given that a firm is financially distressed is -1.21 , suggesting that for financially distressed firms, a restructuring is perceived as a positive and significant event $(\mathrm{t}=2.12, \mathrm{p}=$ 0.034). These results support H2a.

Panel E presents the results of estimating equation (4). The explanatory power of the equation increases over the previous models, with an adjusted $\mathrm{R}^{2}$ of 0.407 . FD as an indicator variable retains its negative and significant coefficient, as expected $(|t|=1.73, p=0.087)$. Coefficients on the interaction terms FDTERM and FDWDN are negative but not significant. This suggests that layoffs and writedowns are perceived as positive events (Eq. 2, Panel C) by the market, but that there is no difference in the market's perception of these disclosures based on whether or not the firm exhibits signs of financial distress. The interaction term FDEXIT has a positive and significant coefficient of $9.687(\mathrm{t}=1.83, \mathrm{p}=0.070)$. Combining the two exit coefficients, the effect of exit cost disclosures given that a firm is financially distressed is $10.478(\mathrm{t}=1.92, \mathrm{p}=0.080)$. This indicates that investors perceive this disclosure negatively. This category is typically analogous to a "miscellaneous" classification. This result is consistent with the results obtained by Lopez (2002) for analysts' year-ahead forecast revisions. Lopez suggests that analysts penalize firms for failure to clearly explain costs that they have incurred. Our results suggest that this is particularly important for firms in poor financial health who fail to disclose the details of costs incurred (or expected to be incurred) as a result of restructuring activities.

The coefficient for the interaction term FDUNCL is negative and significant $(|t|=3.62, p=0.001)$. Combining the two unclassified coefficients, the effect of supplemental disclosure containing specific information not disclosed elsewhere given that a firm is financially distressed is $-4.639(\mathrm{t}=3.24, \mathrm{p}=0.001)$. This suggests that investors view this additional disclosure as positive, and is consistent with the interpretation of the results for FDEXIT. To ensure that this effect is not a result of combining disclosures into one category, we exclude contract terminations, lease terminations, and legal costs and repeat disaggregate regression equations (2) and (4). Results (not tabulated) were substantially unchanged for both equations.

The coefficient on the restructuring component CLOSE is not significant in either of the disaggregated disclosure regressions, consistent with results reported by Lopez (2002) for his one-year ahead analyst forecast revision study. Lopez suggests that within the context of a restructuring, analysts recognize that such events have short-term costs that decrease earnings, but that these costs are partially offset by the expectation of future benefits relative to the closing. Blackwell et al. (1990) hypothesize an increase in firm value if the present value of expected cash benefits exceeds the discounted value of future cash flows from the plant, but find significant negative returns for plant closing announcements, which they attribute to the declining profitability that caused the plant closing. For a distressed firm, these two effects could be offsetting. Another explanation would involve the accounting disclosure policy of the restructuring firm. For example, if unspecified exit costs included costs associated with facility closings, then there could be an impact on the results obtained for both categories. Overall, the results of regression equation (4) suggest that the relation of returns to the disaggregated components of restructuring charges differs for financially healthy and financially distressed firms, and support $\mathrm{H} 2$ (b).

\subsection{Additional Tests}

Tests are repeated to include firms that reported restructuring charges in the year prior to the sample year. Based on prior research, we expect the coefficients to decrease in magnitude and in significance. Results are presented in Table 5. Panel $\mathrm{C}$ indicates that the writedown component of the charge, WDN, retains its (reduced) 
Table 5: Cross-Sectional Regressions Of Annual Stock Returns

On Operating Income, Change In Operating Income, And Restructuring Charges:

Includes Firms With Prior Year Restructuring Charge

$R_{\mathrm{i}, \mathrm{t}}=\gamma_{0}+\gamma_{1} N E+\gamma_{2} \square N E+\gamma_{3} F D_{\mathrm{i}, \mathrm{t}}+\gamma_{4} T E R M+\gamma_{5} F D^{*} T E R M+\gamma_{6} E X I T+\gamma_{7} F D^{*} E X I T+\gamma_{8} C L O S E+\gamma_{9} F D^{*} C L O S E+\gamma$
$10 W D N+\gamma_{11} F D^{*} W D N+\gamma_{12} U N C L+\gamma_{14} F D^{*} U N C L+e$

All independent variables except the indicator variable $F D$ are scaled by $M V E_{t-1}$

\begin{tabular}{|c|c|c|c|c|c|c|c|c|c|c|c|}
\hline \multirow{2}{*}{$n=137$} & & \multicolumn{10}{|c|}{ Parameter estimates (p values in parentheses) } \\
\hline & & $(\mathbf{A})$ & & (B) & & $(\mathbf{C})$ & & (D) & & $(\mathbf{E})$ & \\
\hline \multirow{2}{*}{\multicolumn{2}{|c|}{ Intercept }} & 0.160 & & 0.130 & & 0.109 & & 0.188 & & 0.118 & \\
\hline & & $(0.000)$ & $* * *$ & $(0.008)$ & $* * *$ & $(0.029)$ & $* *$ & $(0.005)$ & $* * *$ & $(0.096)$ & $*$ \\
\hline \multirow{2}{*}{\multicolumn{2}{|c|}{$N E(+)$}} & 0.182 & & 0.077 & & 0.116 & & 0.064 & & 0.216 & \\
\hline & & $(0.243)$ & & $(0.387)$ & & $(0.334)$ & & $(0.410)$ & & $(0.223)$ & \\
\hline \multirow[t]{2}{*}{$\triangle N E$} & & 0.535 & & 1.690 & & 1.813 & & 1.807 & & 2.062 & \\
\hline & & $(0.007)$ & $* * *$ & $(0.001)$ & $* * *$ & $(0.001)$ & $* * *$ & $(0.001)$ & $* * *$ & $(0.001)$ & $* * *$ \\
\hline \multirow[t]{2}{*}{$F D$} & & & & & & & & -0.113 & & -0.066 & \\
\hline & & & & & & & & $(0.049)$ & $* *$ & $(0.480)$ & \\
\hline \multicolumn{2}{|l|}{ RESTRUCT } & & & -0.184 & & & & 0.528 & & & \\
\hline \multirow{3}{*}{\multicolumn{2}{|c|}{$F D^{*} \operatorname{RESTRUCT}(+)$}} & & & $(0.527)$ & & & & $(0.179)$ & & & \\
\hline & & & & & & & & -1.464 & & & \\
\hline & & & & & & & & $(0.004)$ & $* * *$ & & \\
\hline \multirow{2}{*}{\multicolumn{2}{|c|}{ TERM }} & & & & & -1.712 & & & & -3.304 & \\
\hline & & & & & & $(0.138)$ & & & & $(0.240)$ & \\
\hline \multirow[t]{2}{*}{$E X I T$} & & & & & & 0.692 & & & & 0.527 & \\
\hline & & & & & & $(0.375)$ & & & & $(0.485)$ & \\
\hline \multirow[t]{2}{*}{ CLOSE } & & & & & & 0.688 & & & & 0.457 & \\
\hline & & & & & & $(0.184)$ & & & & $(0.396)$ & \\
\hline \multirow[t]{2}{*}{$W D N$} & & & & & & -0.896 & & & & -1.573 & \\
\hline & & & & & & $(0.076)$ & $*$ & & & $(0.139)$ & \\
\hline \multirow[t]{2}{*}{$U N C L$} & & & & & & -0.336 & & & & 3.487 & \\
\hline & & & & & & $(0.764)$ & & & & $(0.040)$ & $* *$ \\
\hline \multirow[t]{2}{*}{$F D * T E R M$} & & & & & & & & & & 0.871 & \\
\hline & & & & & & & & & & $(0.781)$ & \\
\hline \multirow[t]{2}{*}{$F D^{*} E X I T$} & & & & & & & & & & 11.400 & \\
\hline & & & & & & & & & & $(0.026)$ & $* *$ \\
\hline \multirow{2}{*}{\multicolumn{2}{|c|}{$F D^{*} C L O S E$}} & & & & & & & & & 2.466 & \\
\hline & & & & & & & & & & $(0.185)$ & \\
\hline \multirow{2}{*}{\multicolumn{2}{|c|}{$F D * W D N$}} & & & & & & & & & -0.853 & \\
\hline & & & & & & & & & & $(0.509)$ & \\
\hline \multirow{2}{*}{\multicolumn{2}{|c|}{$F D * U N C L$}} & & & & & & & & & -7.329 & \\
\hline & & & & & & & & & & $(0.002)$ & $* * *$ \\
\hline \multicolumn{2}{|l|}{ Adj $R^{2}$} & 0.123 & & 0.266 & & 0.284 & & 0.293 & & 0.359 & \\
\hline Prob F & & $(0.001)$ & & $(0.001)$ & & $(0.001)$ & & $(0.001)$ & & $(0.001)$ & \\
\hline$* \mathrm{p}<0.10$ & $* * \mathrm{p}<0$ & , $* * * \mathrm{p}<$ & & & & & & & & & \\
\hline$N E$ & $=$ Pretax & erating incor & xcludi & structu & trgen & ime $t$ & & & & & \\
\hline$\triangle N E$ & $=$ Chang & pretax oper & incom & excluding $r$ & ecturin & harges, fro & ne $t-1$ & net & & & \\
\hline$F D$ & $=$ Indica & variable that & als one & a firm is clc & ied as & ncially dis & ed and & o otherwise & & & \\
\hline$F D^{*}()$ & $\begin{aligned}= & \text { Financ } \\
& \text { CLOS }\end{aligned}$ & $\begin{array}{l}\text { distress ind } \\
V D N \text {, and } U N\end{array}$ & $r$, inter & ted with vo & les $R E$ & RUCT and & 4 restr & ring charg & ompone & ariables TERM, & EXIT, \\
\hline RESTRUCT & $=$ Restru & ring charge c & e t. & & & & & & & & \\
\hline MVEt-1. & $=$ Marke & lue of equity & me $t-1$ & & & & & & & & \\
\hline Restructuring & charge co & onent variab & & & & & & & & & \\
\hline$\overline{T E R M}$ & $=$ Emplo & severance a & paratio & costs & & & & & & & \\
\hline EXIT & $=$ Exit co & & & & & & & & & & \\
\hline CLOSE & $=$ Facilit & losing costs & & & & & & & & & \\
\hline$W D N$ & $=A s s e t \gamma$ & edowns & & & & & & & & & \\
\hline$U N C L$ & D & iiled costs no & egorize & lsewhere & & & & & & & \\
\hline
\end{tabular}


significance at the disaggregated level, and that TERM loses its significance. The combined restructuring component coefficients (significance levels) in Panel D decrease from -1.212 (0.034) to -0.937 (0.039). Panel E indicates that the combined coefficient for exit costs, EXIT, given financial distress increases in magnitude (significance level) from $10.478(0.080)$ to $11.927(0.027)$. This result was not expected, and could suggest that if failure to provide clear disclosure is penalized by the market, then the penalty is larger if the distressed firm has reported a restructuring charge in the prior year. The combined coefficient for UNCL (supplemental) disclosure given financial distress decreases only slightly in magnitude (significance) from -4.64 (0.001) to -3.84 (0.002), highlighting the importance for distressed firms of providing additional information to investors. In additional tests, we eliminate firms whose restructuring charge consists of one component (i.e., termination costs only or exit costs only) to see if these disclosures could be driving the results. Regression results (not tabulated) were unchanged as a result eliminating these firms from the sample.

The results in this study were obtained using a measure of financial distress based in part on Altman's Zscore model, consistent with prior research. This model was developed specifically for manufacturing firms (Altman 1968, 2002). Tests were repeated using the Altman Z-score for manufacturing firms, and the composite measure for non-manufacturing firms. Results (not tabulated) for distress equations (3) and (4) are consistent with results obtained using the composite measure.

\section{Conclusion}

This study examines the relation between stock returns and the mandatory disaggregated financial statement footnote disclosure of restructuring charges for firms that are undergoing an operational restructuring. In particular, we use interactive dummy variables to see if the relation between these disclosures and returns differs depending on a firm's financial health.

We find significant coefficients on disaggregated components of restructuring charges in a regression of returns on earnings, earnings changes, and restructuring charge components. We provide evidence that for firms that exhibit signs of financial distress, aggregate restructuring charges are priced differently than they are for financially healthy firms. Further, we show that disaggregated components of the restructuring charge are priced differently for financially distressed firms than they are for healthy firms, and that this difference is significant. Results suggest that for financially distressed firms, investors perceive supplemental disclosure as a positive signal of the firm's future operating performance, and view a disclosure that lacks detail and/or clarity negatively.

The SEC has made continuing efforts to monitor restructuring charges, and has most recently reinforced its position on the importance of restructuring activities to investors by proposing required disclosure on Form $8 \mathrm{~K}$. The recent adoption of SFAS No. 146 underscores the FASB's emphasis on the importance to financial statement users of both timing and disclosure issues related to restructuring charges. Overall, this study provides evidence that for restructuring charges, disaggregated component disclosure provides information to investors above that contained in the aggregate charge. Thus, the results of this study support the continuing efforts of regulatory authorities to require standard, expanded financial statement disclosure that is value-relevant to investors.

\section{Suggestions For Future Research}

This study has limitations, some of which provide interesting opportunities for future research. The results of our study are conditioned on the chosen measure of financial distress, and could be sensitive to alternative financial distress measures. In view of the increasing numbers of reported restructuring activities and the increase in corporate bankruptcies (Altman, 2002), the study could be extended to determine whether the results hold across time. An examination of management changes, prior merger activity, prior disclosure practices, and prior restructuring activities that could impact investors' perceptions of current year restructuring activities could provide additional insight into the results presented. An analysis of industry effects could add another dimension to the results. The effects of restructuring disclosures on creditors' perceptions, rather than on investors' perceptions, could provide an interesting extension to the study. 


\section{Endnotes}

1. For example, Healy and Palepu (2001) suggest that firms may increase voluntary disclosure when they are performing well, and that this self-selection bias could result in an association with returns driven not by disclosure, but by firm performance. Additionally, Linsmeier et al. (2002) provide empirical evidence suggesting that mandatory quantitative forward-looking footnote disclosures of exposures to market risk provide information that is interpreted and acted upon by users, while risk disclosures that are not required remain difficult to interpret, and less value-relevant.

2. SAB's are interpretations followed by the SEC's Division of Corporation Finance and the Office of the Chief Accountant when administering disclosure requirements of Federal securities laws. Registrants are encouraged, but not required, to comply with their provisions.

3. SFAS No. 146 cites the definition of restructuring set forth in International Accounting Standard No. 37 (IAS 37, 1999, par. 10): "a programme that is planned and controlled by management, and materially changes either: (a) the scope of a business undertaken by an enterprise; or (b) the manner in which that business is conducted." Economic events that constitute a restructuring include the sale or termination of a line of business, closure or relocation of business activities at a particular location, changes in management structure, and a reorganization that affects the nature and focus of operations (IAS 37, par. 70).

4. The primary result of the use of this composite measure was the reclassification of 15 of the 16 largest firms in the sample, each with assets in excess of $\$ 4$ billion, from the "distressed" category indicated by Altman's Z to the "healthy" category. Classifications for other firms were generally consistent between the two measures.

5. The 15 large firms that were reclassified from the "distressed" to the "healthy" category as a result of using an extended distress measure, achieved a mean (median) Altman's Z-score of 1.22 (1.10). Excluding these firms, the mean (median) Altman's Z-score for firms classified as "healthy" was 1.94 (1.87).

\section{References}

1. Altman, E., "Financial ratios, discriminant analysis, and the prediction of corporate bankruptcy," Journal of Finance 23, pp. 589-609, 1968.

2. Altman, E., "Revisiting credit scoring models in a Basel 2 Environment," Working paper, New York University Stern School of Business, available at http://pages.stern.nyu.edu/ ealtman/, 2002.

3. Andes, S., S. Perry, and N. Thorley, "Evaluating firms in financial distress: an event history analysis," Journal of Applied Business Research 12:3, pp. 60-69, 1996.

4. $\quad$ Barth, M., W. Beaver, and W. Landsman, "The market valuation implications of net periodic pension cost components," Journal of Accounting and Economics 15, pp. 27-62, 1992.

5. Blackwell, D., M. Marr, and M. Spivey, "Plant closing decisions and the market value of the firm," Journal of Financial Economics 26, pp. 277-288, 1990.

6. Easton, P., and T. Harris, "Earnings as an explanatory variable for returns," Journal of Accounting Research 29, pp. 19-36, 1991.

7. Elliott, H., and J. Hanna, "Repeated accounting write-offs and the information content of earnings," Journal of Accounting Research 34 (supplement), pp. 91-126, 1996.

8. Financial Accounting Standards Board, Statement of Financial Accounting Standards No. 146, Norwalk, CT, 2002.

9. Financial Accounting Standards Board Emerging Issues Task Force, EITF Issue 94-3, Liability recognition for certain employee termination benefits and other costs to exit an activity (including certain costs incurred in a restructuring), Norwalk, CT, 1994.

10. Francis, J., J.D. Hanna, and L. Vincent, "Causes and effects of discretionary asset write-offs," Journal of Accounting Research 34 (Supplement), pp. 117-134, 1996.

11. Hayn, C., "The Information Content of Losses," Journal of Accounting and Economics 20, pp. 125-154, 1995.

12. Healy, P., and K. Palepu, "Information asymmetry, corporate disclosure, and the capital markets: a review of the empirical disclosure literature," Journal of Accounting and Economics 31, pp. 405-440, 2001. 
13. Hogan, C.E., and D.C. Jeter, "The information content of restructuring charges: a contextual analysis," Working paper, Vanderbilt University, 1998.

14. International Accounting Standards Committee (IASC). International Accounting Standards. London, U.K., 1999.

15. Iqbal, Z. and A. Akhigbe, "Changes in corporate performance associated with layoffs," Journal of Financial and Strategic Decisions 10, pp. 17-26, 1997.

16. Iqbal, Z., and S. Shetty, "Layoffs, stock price, and financial condition of the firm," Journal of Applied Business Research 11:2, pp. 67-72, 1995.

17. Khurana, I., and B.Lippincott, "Restructuring and firm value: the effects of profitability and restructuring purpose," Journal of Business, Finance, and Accounting 27, pp. 1107-1129, 2000.

18. Kross, W., T. Park, and B. Ro, "The impact of operational restructuring announcements on stock price, risk, and trading volume," Working paper, Purdue University, 1998.

19. Leuz, C. and Verrecchia, R., "The economic consequences of increased disclosure," Journal of Accounting Research 38 (supplement), pp. 91-124, 2000.

20. Levitt, A., "The Numbers Game," speech delivered at New York University Center for Law and Business, (September 28), 1998.

21. Linsmeier, T., D. Thornton, M. Venkatachalam, and M. Welker, "The effect of mandated market risk disclosures on trading volume sensitivity to interest rate, exchange rate, and commodity price movements," The Accounting Review 77, pp. 343-377, 2002.

22. Lopez, T.J., "Evidence on the incremental information contained in the components of restructuring charges," Journal of Business, Finance, and Accounting, 29, pp. 613-659, 2002.

23. Moehrle, S., 2002, "Do firms use restructuring charge reversals to meet earnings targets?" The Accounting Review 77, pp. 397-413.

24. Scheutze, W., "Cookie Jar Reserves," Speech delivered at the Corporate Securities and Law Institute, Northwestern University, Evanston, IL., April 22, 1999.

25. Securities and Exchange Commission, Staff Accounting Bulletin No. 67, Income statement presentation of restructuring charges, 1986.

26. Securities and Exchange Commission, Staff Accounting Bulletin No. 100, Restructuring and impairment charges, 1999.

27. Securities and Exchange Commission, Proposed Rule under SEC 17 CFR Parts 228, 229, 240, and 249, www.sec.gov, June 19, 2002.

28. Wilson, G., 1996, Discussion: write-offs: manipulation or impairment? Journal of Accounting Research 34 (Supplement), 171-177.

\section{Appendix \\ Sample Restructuring Footnote Disclosures}

\section{Chart House, Inc., December 31, 1995}

(2) Restructuring

In 1995, the Company adopted a new strategic plan to improve shareholder returns by refocusing on its core business - Chart House restaurants. The Company's Board of Directors approved management's recommendation to sell the Islands and Paradise Bakery restaurant operations and to modernize, revitalize, and expand the Chart House restaurant concept. As part of the strategic plan the Company also decided to dispose of selected underperforming Chart House restaurants and implement a plan for reorganizing the management team and reducing administrative and operational overhead costs.

As of December 31, 1995, the Company had completed the sale of Paradise Bakery, Inc. (see Note 3) and had begun preliminary negotiations to sell its Islands restaurant division (see Note 14).

The restructuring actions resulted in charges to income in the fourth quarter of 1995 of $\$ 4,853,000$ before income taxes. Approximately $\$ 4,443,000$ of these charges relate to the Company's decision to dispose of three Chart House restaurants and two former Chart House restaurant properties. The charges include amounts to write 
down assets to their estimated net realizable value and estimated costs related to ceasing operations and selling the restaurants. Included in the property and equipment in the accompanying consolidated balance sheet at December 31,1995 is approximately $\$ 2.1$ million of assets held for disposal. The remainder of the restructuring charges consist of severance and related expenses for certain management employees.

The amount of write-down and resulting carrying value of the respective assets at December 31, 1995 include management's best estimates of the amounts to be realized on the disposition of the assets. The amounts the Company will ultimately realize may differ from the amounts assumed in arriving at the aforementioned writedown.

J. Baker, Inc. and Subsidiaries, February 3, 1996

2. Disposition of Fayva Shoe Division

In the year ended February 3, 1996, the Company recorded restructuring charges of $\$ 69.3$ million (which had an after-tax effect of $\$ 41.6$ million or $\$ 3.00$ per share) as a result of the liquidation of the Company's Fayva footwear division. Restructuring charges include actual costs for employee severance and other benefits of $\$ 3.5$ million (a total of 2,545 full and part-time employees were terminated), fixed asset write-offs of $\$ 18.5$ million and a loss on the disposal of inventory of $\$ 20.5$ million. Also included in the restructuring charges is a charge of $\$ 26.8$ million for costs related to the disposition of the Fayva store leases.

Accrued at February 3, 1996 are severance and lease termination costs of $\$ 13.3$ million. These costs are expected to be paid by the end of the next fiscal year.

Notes 
Notes 